\title{
O USO ESPONTÂNEO DE ANALOGIAS POR PROFESSORES DE BIOLOGIA: OBSERVAÇÕES DA PRÁTICA PEDAGÓGICA ${ }^{1}$
}

\section{THE SPONTANEOUS USE OF ANALOGIES BY BIOLOGY TEACHERS: OBSERVATIONS OF PEDAGOGICAL PRACTICE}

\author{
Daniela Frigo Ferraz- Mestre em Educação, UFSM \\ Eduardo Adolfo Terrazzan- Depto. Metodologia do Ensino, UFSM
}

\section{Resumo}

Este artigo é fruto de uma dissertação de mestrado onde evidenciamos o uso de analogias e metáforas de forma espontânea por professores de Biologia no Ensino Médio. Contrariamente à nossa expectativa inicial, baseada na forte presença das coleções didáticas na prática pedagógica dos professores em geral, em nossas observações evidenciamos que poucas das analogias utilizadas coincidem com aquelas presentes nas coleções didáticas adotadas pelas professoras sujeitos da pesquisa. Detectamos outras fontes de onde podem proceder as analogias utilizadas pelos docentes que são apresentadas e discutidas neste texto. Além disso discutimos os resultados referentes a incorporação das analogias ao planejamento pessoal das professoras sujeitos dessa pesquisa.

Palavras-chave: formação inicial de professores, prática de ensino de física, saberes docentes

\section{Abstract}

This study comes from a Master's dissertation which tries to make evidencies of the use of analogies and metaphors on a spontaneous way by high school biology teachers. Opposite to one's starting expectation based on the strong presence of didactic collections on the didactic practice of teachers in a general way, in the observations one evidenced that few of the used analogies are the same as the ones present in the didactic collections adopted by the teachers that were subject of the research. One detected another sources from which can come the analogies that are presented and discussed in this text. Besides it, one discusses the results refering to the incorporation of analogies in the personal planning of the referred teachers.

key-words: pre-service teacher education, physics teaching methods courses, teacher knowledge

\footnotetext{
${ }^{1}$ Apoio parcial CAPES
} 


\section{INTRODUÇÃO}

Nos últimos anos têm sido considerável o crescimento do interesse de educadores/pesquisadores de ciências pelo uso de analogias no Ensino de Ciências, principalmente no âmbito internacional (Glynn et. al. (1998); Harrison \& Treagust (1994); Ogborn \& Martins (1996); Venville \& Treagust (1996); Wilbers \& Duit (2001). Esse interesse pode ser considerado razoável, já que as analogias fazem parte do processo cognitivo humano e ainda auxiliam na compreensão dos conceitos científicos por aproximarem dois domínios heterogêneos. Ou seja, um domínio menos familiar (conceito científico a ser esclarecido), que chamaremos de "alvo" é tornado compreensível por semelhança com um domínio mais familiar, que chamaremos de "análogo" (Glynn et al., 1998). Assim é estabelecida uma relação entre um domínio menos conhecido com um domínio mais conhecido. Este será o conceito por nós adotado. Um exemplo de uma analogia clássica utilizada na história da Biologia é a da escada de corda torcida para explicar a estrutura da molécula de DNA. O análogo (domínio usado como base para comparações estruturais) no exemplo citado seria a escada de corda e o alvo (domínio a ser explicado) seria a molécula de DNA.

Por outro lado, poucos são os trabalhos encontrados na literatura sobre o uso espontâneo de analogias por professores durante sua prática pedagógica, que é o foco do presente estudo.

Através de levantamento bibliográfico na literatura sobre analogias, conseguimos perceber que era possível classificar três grupos de investigações que tratam sobre o uso de analogias como ferramentas no processo de ensino. Primeiramente, foi feito um levantamento mais amplo para conhecer e compreender o que era produzido na área e para localizar os trabalhos que tratavam sobre o uso de analogias por professores no contexto escolar.

Desse levantamento mais amplo, percebemos que existiam trabalhos que se referiam a avaliação de estratégias didáticas para um uso efetivo de analogias para a construção de conceitos científicos. Em alguns casos, os autores se utilizavam de análises de textos didáticos como base para construção de estratégias didáticas para sala de aula. Por exemplo, Glynn et al. (1998) desenvolve o modelo TWA (Teaching with Analogies) a partir de uma análise de livros texto de Ciências. Um segundo grupo de trabalhos se referia ao uso de analogias presentes em textos didáticos (Curtis \& Reigeluth (1984); Thiele \& Treagust (1995); Dagher (1994); Iding (1997); Terrazzan et al. (2000). Por fim, o terceiro grupo de trabalhos tratava sobre o uso de analogias tal como elas são utilizadas no contexto escolar, ou seja, tal como são utilizadas por professores em sala de aula.

\section{O USO DE ANALOGIAS POR PROFESSORES EM SALA DE AULA}

Poucos são os trabalhos existentes nesse campo, mas nos deteremos um pouco mais nesse item já que o foco dessa pesquisa se centrará no uso de analogias por professores em sua prática pedagógica durante o ensino de biologia. Duit (1991) aponta dois trabalhos em que os professores são observados com o intuito de focalizar o uso de metáforas ou analogias em sua fala. O primeiro deles é o trabalho de Tierney (1988) que 
observou quatro professores de estudos sociais durante 20 aulas. Tierney (1988) ressalta a maneira limitada com que as comparações são realizadas e a ausência de controle a respeito de como os alunos as interpretam, já que pressupõem que os estudantes estavam familiarizados com o domínio análogo e que poderiam usar metáforas, analogias e similares sem qualquer orientação. O segundo trabalho se refere a um estudo de Treagust et al. (1990) e está relacionado a observação de aulas de ciências (40 aulas de 8 professores). Os professores, nesse estudo, raramente usaram analogias no seu ensino (nas quarenta aulas observadas, somente em oito delas foram detectadas). Quando estes professores usavam analogias, estas não eram usadas de uma forma elaborada. Neste estudo, os autores detectaram que os professores analisados pareciam não ter um repertório de boas analogias e não estavam seguros com relação ao uso efetivo destas.

Treagust et. al. (1992) realizam observações de sete professores durante suas aulas de ciências, com o objetivo de examinar como esses professores usavam analogias como parte de seu ensino regular para ajudar os estudantes a compreender conceitos científicos. Após as quatro semanas de observações, cada professor foi entrevistado sobre sua visão do uso de analogias no ensino. Durante todas as observações feitas, somente seis indicações claras do uso de análogos foram encontradas. Para as análises, os autores basearam-se em Curtis \& Reingeluth (1984), três das seis analogias observadas eram do tipo simples de comparação e três eram enriquecidas. Os autores sugerem, que para um uso efetivo de analogias em aulas regulares de ciências, estas precisariam ser baseadas em um repertório bem preparado de analogias, usadas em conteúdos específicos e em contextos específicos.

Thiele \& Treagust (1994) analisaram o uso de analogias por quatro professores de química. Cada um destes professores admitia usar analogias para ensinar química e sabia que o foco da pesquisa era sobre o uso de analogias no ensino de química. No total, foram observadas 43 aulas entre os quatro professores, sendo que os mesmos utilizaram-se de 45 analogias. Especificamente, neste estudo, os autores se detiveram em pesquisar três questões principais: 1) Por que os professores escolheram usar analogias quando estavam ensinando química. 2) De onde derivavam as analogias utilizadas por estes professores e 3) Como as características das analogias utilizadas variavam de professor para professor. Em relação a primeira questão, os autores destacaram que os docentes utilizavam analogias quando consideravam que os alunos não conseguiam compreender a explicação inicial. Em relação a segunda questão, os autores apontam que, normalmente, as analogias utilizadas pelos professores não foram planificadas com anterioridade à aula, ou seja, as analogias aparecem de uma forma espontânea na hora de explicação. Houveram evidências de que cada professor mantinha mentalmente um repertório de analogias em seu trabalho e que eram recuperadas na hora de estimular os estudantes a responder uma questão. Assim, foi detectado que os professores recorrem à sua própria experiência ou leitura profissional como fonte de analogias. Para responder a terceira questão, ou seja, determinar as características das analogias utilizadas pelos professores os autores determinaram algumas categorias de análise.

Dagher (1995) faz um estudo bastante aprofundado em relação ao uso de analogias em sala de aula. Observa 20 professores de ciências. Destes, somente 11 usaram analogias em seu discurso verbal. Utiliza-se de um método que chama de "método naturalístico de análise", pois acredita que as analogias observadas são únicas, exibindo diferentes 
estruturas e funções, dependendo de seu contexto. Assim, antes de usar esquemas de classificação preestabelecidos ou buscar padrões para criar um novo esquema, a autora prefere investigar as analogias utilizadas pelos professores como eventos únicos fixados em contextos específicos. Após as observações das analogias encontradas, a autora cria episódios de análise. Os domínios analógicos selecionados incluem experiências da vida cotidiana (resfriados comuns), observações de experiências da vida (polícia, carteira de motorista), ficção científica (aliens), histórias personalizadas (crianças em um bote) e objetos comuns (baterias). Isto mostra a preocupação dos professores em trazer situações cotidianas para expressar os conceitos científicos numa linguagem comum. Os professores tecem as analogias naturalmente em sua discussão e a desenvolvem com mais ou menos extensão, dependendo, talvez, da percepção do professor da importância do assunto que está tratando. Tampouco se detêm para considerar em que medida as comparações utilizadas são compreendidas pelos alunos, já que os estudantes se comportam como simples ouvintes e só ocasionalmente como participantes ativos.

Pensamos ser de fundamental importância trabalhos descritivos sobre como os professores usam analogias nas suas aulas, como os comentados anteriormente, para um melhor entendimento sobre sua função em sala de aula. Desenvolver uma melhor compreensão sobre o que os professores fazem naturalmente é necessário para que, conhecendo os elementos componentes da prática pedagógica, os mesmos possam analisá-los e repensá-los.

Ressalta-se ainda que o presente trabalho é parte de um estudo mais amplo onde adotou-se três eixos para analisar as analogias presentes nas atividades de ensino das professoras sujeitos da pesquisa. No primeiro deles, organizamos os resultados gerais referentes ao uso espontâneo de analogias em sala de aula, analisando o nível de organização das analogias utilizadas. Em um segundo eixo, analisamos e discutimos as fontes de onde provêm as analogias utilizadas pelas professoras. Ainda, em um terceiro eixo, apresentamos os resultados obtidos em relação à incorporação das analogias ao planejamento didático-pedagógico pessoal das professoras. Neste trabalho, discutimos os resultados referentes ao segundo e terceiro eixo citados.

\section{ASPECTOS METODOLÓGICOS}

As analogias mapeadas nesse trabalho foram fruto de um levantamento realizado pela observação e audio-gravação das aulas de seis professoras, sujeitos de nossa pesquisa. É importante salientar que optamos por revelar os objetivos da pesquisa ao grupo o que pode e certamente deve ter promovido interferência nos dados obtidos. Mesmo assim, mantivemos essa postura por acreditar ser mais ética.

Em um primeiro momento procedemos a observação das aulas de quatro professoras (professoras 1, 2, 3 e 4) em uma 1a série do Ensino Médio do Colégio Estadual Manoel Ribas. A escolha dessas professoras se deu pela nossa facilidade de contato com as mesmas, bem como o seu consentimento para a observação de suas aulas.

Em um segundo momento, demos continuidade as observações, em outras escolas (Maria Rocha e Coronel Pillar) com outras duas professoras (professoras 5 e 6 ) em uma $2^{\text {a }}$ série do Ensino Médio. O critério para a escolha destas escolas e séries decorreu da 
escolha das professoras. Para a escolha das professoras, nesta segunda etapa de observações, adotamos como critérios:

1. Duas foram escolhidas entre as já observadas no semestre anterior e que mais utilizaram analogias durante as observações anteriores (Professoras 1 e 2). Sendo a professora 1 em uma $2^{\mathrm{a}}$ série do Ensino Médio e a professora 2 em uma $1^{\text {a }}$ série do Ensino Médio. Ambas do Colégio Estadual Manoel Ribas.

2. Uma (Professora 6), da Escola Estadual de $1^{0}$ e $2^{\underline{0}}$ graus Coronel Pilar, ministrando aulas para $2^{\text {a }}$ série do Ensino Médio.

3. Uma (Professora 5), do Colégio Estadual Prof. Maria Rocha, ministrando aulas para $1^{\underline{a}}$ série do Ensino Médio foi escolhida por conhecermos a referida professora e seu trabalho, o que facilitou nosso contato e entrada em suas aulas.

Com o objetivo de detectar as fontes de onde procediam as analogias utilizadas empregamos a análise documental nos livros didáticos. Em nossa investigação, utilizamos os livros didáticos de biologia que haviam sido selecionados entre os mais utilizados nas escolas estaduais de Ensino Médio de Santa Maria e também os quadros-síntese elaborados a partir dos livros didáticos no projeto "Linguagem e formação de Conceitos: Implicações para o Ensino de Ciências Naturais". Assim, confrontávamos as analogias utilizadas pelas professoras com as analgias presentes nos livros didáticos por nós analisados anteriormente (Terrazzan et al. 2000).

Realizamos ainda uma entrevista semi-estruturada com todas as professoras sujeitos da pesquisa. As entrevistas foram realizadas diretamente pela pesquisadora, através de conversas previamente marcadas, com roteiro que orientou o desenrolar da mesma. $O$ objetivo principal da entrevista foi detectar como se dava o planejamento das aulas.

\section{RESULTADOS E DISCUSSÃO}

No total, a partir das observações sobre o uso espontâneo de analogias pelas professoras escolhidas, podemos identificar 108 ocorrências. No Colégio Estadual Manoel Ribas, no período de setembro a dezembro de 2000, na observação de 65 aulas, obtivemos um total de 56 analogias utilizadas. Já no período de março a junho de 2001, obtivemos um total de 52 analogias em 87 aulas observadas nos colégios Manoel Ribas, Maria Rocha e Coronel Pillar (Quadros I e II).

\begin{tabular}{|c|c|c|c|c|}
\cline { 3 - 4 } \multicolumn{2}{c|}{} & \multicolumn{2}{c|}{ PERÍODO 25/09/2000 a 06/12/2000 } \\
\hline ESCOLA & SÉRIE & PROFA. & $\begin{array}{c}\text { No DE AULAS } \\
\text { OBSERVADAS }\end{array}$ & $\begin{array}{c}\text { No DE ANALOGIAS } \\
\text { UTILIZADAS }\end{array}$ \\
\hline \multirow{3}{*}{$\begin{array}{c}\text { Colégio Estadual } \\
\text { Manoel Ribas }\end{array}$} & $1^{\underline{a}}$ & 1 & 15 & 24 \\
\cline { 2 - 5 } & $1^{\underline{a}}$ & 2 & 21 & 16 \\
\cline { 2 - 5 } & $1^{\underline{a}}$ & 3 & 10 & 16 \\
\cline { 2 - 5 } & $1^{\underline{a}}$ & 4 & 19 & 00 \\
\hline
\end{tabular}

QUADRO I - Número de aulas observadas e número de analogias utilizadas pelas professoras no período de setembro a dezembro de 2000. 


\begin{tabular}{|c|c|c|c|c|}
\hline ESCOLA & SÉRIE & PROFA. & $\begin{array}{c}\text { PNo DE AULAS } \\
\text { OBSERVADAS }\end{array}$ & $\begin{array}{c}\text { № DE ANALOGIAS } \\
\text { UTILIZADAS }\end{array}$ \\
\hline \multirow{2}{*}{$\begin{array}{c}\text { Colégio Estadual } \\
\text { Manoel Ribas }\end{array}$} & $2^{\text {a }}$ & 1 & 27 & 13 \\
\cline { 2 - 5 } & $1^{\text {a }}$ & 2 & 14 & 06 \\
\hline $\begin{array}{c}\text { Colégio Estadual } \\
\text { Prof. Maria Rocha }\end{array}$ & $1^{\text {a }}$ & 5 & 29 & 17 \\
\hline $\begin{array}{c}\text { Escola Estadual de } \\
1^{\circ} \text { e 20 graus } \\
\text { Coronel Pilar }\end{array}$ & $2^{\text {a }}$ & 6 & 17 & 52 \\
\hline
\end{tabular}

QUADRO II- Número de aulas observadas e número de analogias utilizadas pelas

professoras no período de março a junho de 2001.

O número significativo de analogias encontradas mostram o quanto as analogias estão presentes no processo de ensino. São recursos didáticos que os professores lançam mão para auxiliarem o processo de ensino-aprendizagem. Logicamente que nem todas as analogias utilizadas foram totalmente pertinentes, do ponto de vista de seu uso, no ensino dos conteúdos desenvolvidos. Alguns tipos se mostraram mais eficientes, quer dizer, quando a professora utilizava a analogia organizada de uma determinada forma esta parecia mais adequada para o ensino.

\section{AS FONTES DE ONDE PROVÊM AS ANALOGIAS UTILIZADAS PELAS PROFESSORAS}

Comparando as analogias utilizadas pelas professoras com as dos quadros-síntese dos levantamentos realizados anteriormente em coleções didáticas (Terrazzan et al. 2000), constatamos coincidência somente em 02 (dois) casos. Em outros 19 (dezenove) casos, alvo e análogo utilizados eram semelhantes, mas os encaminhamentos dados foram diferentes dos apresentados nas coleções didáticas. A maioria das analogias utilizadas pelas professoras 87 (oitenta e sete) tinham alvo e análogo diferentes dos apresentados nas coleções didáticas de referência (Tabela 1).

Contrariamente à nossa expectativa inicial, baseada na forte presença das coleções didáticas na prática pedagógica dos professores em geral, em nossas observações, evidenciamos que poucas das analogias utilizadas coincidem com aquelas presentes nas coleções didáticas adotadas pelas professoras. Isto é confirmado pela porcentagem de analogias da tabela 1 , onde somente $1.86 \%$ das analogias utilizadas pelas professoras coincidem com as apresentadas nas coleções didáticas por nós analisadas. 


\begin{tabular}{|c|c|c|c|c|}
\hline \multirow[t]{2}{*}{ PROFa. } & \multirow[t]{2}{*}{$\begin{array}{l}\text { №. DE ANALOGIAS } \\
\text { UTILIZADAS PELAS } \\
\text { PROFESSORAS }\end{array}$} & \multicolumn{3}{|c|}{$\begin{array}{c}\text { GRAU DE COINCIDÊNCIA ENTRE AS ANALOGIAS } \\
\text { UTILIZADAS EM AULA E AS ANALOGIAS PRESENTES NAS } \\
\text { COLEÇÕES DIDÁTICAS }\end{array}$} \\
\hline & & $\begin{array}{ll} & \text { Mesmo alvo } \\
\text { - } & \text { Mesmo análogo } \\
\text { - } & \text { Mesmo } \\
\text { encaminhamento }\end{array}$ & $\begin{array}{ll}\text { - } & \text { Mesmo alvo } \\
\text { - } & \text { Mesmo análogo } \\
\text { - } & \text { Diferente } \\
\text { encaminhamento }\end{array}$ & $\begin{array}{ll} & \text { Alvo } \\
& \text { diferente } \\
- & \text { Análogo } \\
& \text { diferente }\end{array}$ \\
\hline 1 & 37 & 01 & 02 & 34 \\
\hline 2 & 22 & 00 & 06 & 16 \\
\hline 3 & 16 & 01 & 01 & 14 \\
\hline 4 & 00 & 00 & 00 & 00 \\
\hline 5 & 17 & 00 & 05 & 12 \\
\hline 6 & 16 & 00 & 05 & 11 \\
\hline \multicolumn{2}{|r|}{ TOTAIS } & 02 & 19 & 87 \\
\hline \multicolumn{2}{|c|}{ PERCENTUAL } & $1.86 \%$ & $17.59 \%$ & $80.55 \%$ \\
\hline
\end{tabular}

TABELA 1 - Grau de coincidência entre as analogias utilizadas em aula pelas professoras observadas e as analogias presentes nas coleções didáticas (Terrazzan et al. 2000)

Através das entrevistas realizadas com as professoras, confirmamos o resultado de que poucas analogias utilizadas pelas professoras provêm dos livros didáticos. Detectamos outras fontes de onde podem proceder as analogias utilizadas pelas mesmas. A maioria das professoras diz que o uso de analogias já faz parte de seu "cotidiano", do seu "dia a dia", de sua "criatividade" e da sua "própria experiência profissional", de modo a facilitar o entendimento dos alunos, conforme seqüências que seguem:

\section{SEQÜÊNCIA 01}

1. Entrevistadora: Onde você busca estas analogias que você utiliza?

2. Profa 1: Ah, do cotidiano, sei lá....Não sei te dizer da onde eu busco, eu uso diariamente né. Comparando, o conhecimento que tu tem, é muito maior que o deles, então tu sabe que tu pode comparar uma coisa com a outra, até porque a própria biologia tu pode estudar comparando né? Do cotidiano, do dia a dia.

\section{SEQÜÊNCIA 02}

1. Entrevistadora: O objetivo específico desta entrevista é saber como se dá o planejamento dos professores e também pra gente tentar verificar de onde vêm essas analogias que vocês utilizam nas aulas de vocês.

2. Profa 6: Hum. Da onde? Do além! (Risos) Da onde que eu tirei isso. A maioria... a única que eu não, a única que não é assim, que eu tenha tirado é aquela da escada, porque tá nos livros já; mas o resto é...vem da criatividade, as vezes eu fico matutando como é que eu poderia fazer. E, às vezes, sai do improviso. Às vezes, na aula, assim, aquela da manta, saiu do improviso na aula, só que eu não usei agora porque não tava frio. 
Sendo parte integrante da cognição não é surpreendente o fato de que as professoras sujeitos da pesquisa usem analogias de uma forma espontânea e que estas sejam provindas de sua própria criatividade e experiência profissional.

\section{A INCORPORAÇÃo dAS ANALOGIAS AO PLANEJAMENTO DIDÁtICO- PEDAGÓGICO PESSOAL DAS PROFESSORAS.}

Quanto ao planejamento das professoras sujeitos da pesquisa, percebemos que este é feito de uma maneira automática. Ou seja, as professoras, na grande maioria, seguem um programa preestabelecido, onde é apresentado um rol de conteúdos que deve ser desenvolvidos durante o ano letivo. Este programa, o Programa de Ingresso ao Ensino Superior (PEIES), é hoje uma das principais formas de acesso ao Ensino Superior, juntamente com o tradicional vestibular. Este programa prevê o ingresso a Universidade Federal de Santa Maria, através de um processo seletivo dividido em três fases. Cada fase é referente a uma série do Ensino Médio. Assim, ao final de cada ano letivo, o aluno faz uma prova referente aos conteúdos preestabelecidos pelo programa. O aluno com bom desempenho, nas três etapas, pode ter garantido seu acesso a universidade sem prestar vestibular quando da conclusão deste nível de ensino.

Também, detectamos que, na grande maioria das vezes, as professoras planejam as suas aulas baseados nos livros didáticos adotados, mas sempre recorrem a outras fontes para sua explicação, seja outros livros didáticos, livros que usaram na universidade, revistas, jornais, cursos que participam. A grande maioria das professoras não usa analogias em seu planejamento de maneira explicita. Algumas, como por exemplo a professora 1, até pensam em usar quando estão planejando, quando acham que a linguagem do livro didático é muito difícil para os alunos:

\section{SEQÜÊNCIA 03}

1. Entrevistadora: Primeiramente, eu vou pedir para tu falares um pouquinho como é o planejamento das tuas aulas, como se dá a organização geral do teu planejamento, que pressupostos que tu usas para planejar as tuas aulas.

2. Profa 1: Bom, primeiro né, eu primeiro leio o conteúdo no livro que eles seguem, tá. Aí depois eu procuro em outros livros, que o livros deles (referindo-se ao livro adotado que é o Amabis \& Martho, volume único) tem uma linguagem muito difícil, a linguagem do Amabis é bem difícil, bem complicada, então, eu procuro ler em outros livros para chegar o mais perto do que tá ali né. Para poder comparar e poder explicar melhor, tá? Porque aquela linguagem para eles é difícil. $\mathrm{E}$, assim oh, as analogias que eu uso, assim, eu mesmo busco sabe? Muito pouco se encontra nos livros então eu procuro comparar com alguma coisa.

3. Entrevistadora: Quais são os outros livros que tu usas?

4. Profa 1: Eu uso....

5. Entrevistadora: São livros didáticos ou outros tipos de livros?

6. Profa 1: Livros didáticos, e também assim oh, quando o assunto, sei lá, quando tá muito simplificado ali, eu procuro nos livros da universidade, pra entender o difícil pra depois ir para o mais simples, tá, poder explicar o máximo para eles. 
7. Entrevistadora: Como se dá a utilização deste planejamento que tu elaboras, durante o ano letivo? Tu fazes um planejamento geral pra todo ano? Como é que é?

8. Profa 1: Não, não. Assim, é que a gente já tem as reuniões dos professores e a gente já planeja o conteúdo que tem que ser dado durante o ano todo, tá. Aí, assim: por bimestre a gente tem reunião, a gente planeja o conteúdo pró bimestre. Aí então eu planejo as minhas aulas em cima do bimestre, sabe? Se der tempo de dar mais, eu dou né.

9. Entrevistadora: Quando tu fazes o teu planejamento tu colocas alguma analogia de maneira explícita? Assim: "eu vou usar tal analogia nessa aula aqui."

10. Profa 1: Não. Não coloco. Se bem que eu não preciso escrever, fica guardado na cabeça, eu já sei como é que eu vou falar pra eles, eu não... eu só faço um resumo da matéria, faço um resumo pra...né. Faço no papel, porque eu não uso o livro. O livro é pra eles, sabe. Eu tento modificar aquela linguagem do livro, eu busco...eu falo na minha linguagem, até porque eu escrevo no quadro...eu explico, eu falo: "não, escrevam isso, coisa e tal'. Tá, mas não escrevo assim. Não digo: "vou usar e tal”. Só penso, assim, na hora que eu tô lendo, que eu tô...estudando a matéria eu já penso: "ah, podia comparar com isso, com aquilo".

Outras, como a professora 6, acham que a analogia é uma coisa natural, que já vinha sendo usada durante os vários anos de magistério. Para ela, a analogia "surge" na hora da explicação. Ao mesmo tempo, em algumas falas, afirma que as vezes fica "matutando", fica "planejando", pensando sobre o que poderia fazer para "facilitar" o entendimento dos alunos:

\section{SEQÜÊNCIA 04}

1. Entrevistadora: Voltando um pouco para o planejamento. Tu te baseias em que pra fazeres o teu planejamento?

2. Profa 6: A bibliografia indicada por eles (referindo-se ao programa do PEIS). Mas a maior parte eu pego do Amabis.

3. Entrevistadora: Mais livros didáticos?

4. Profa 6: É. Também quando eu entro na parte de genética, o ano passado eu usei muito a parte do genoma. Eu uso muito o jornal também. Mas eu uso bastante o jornal, revistas, essas coisas assim. Mas assim, mais o, essencialmente é o Amabis, que eu adoto. $E$ me baseio bastante, também, nas apostilas do cursinho, que tem bastante esquema sabe. $O$ esquema facilita muito.

5. Entrevistadora: Então, quando tu fazes teu planejamento, tu não planejas: "Ah, eu vou usar uma analogia". Como que é, tu explicita: "Em tal matéria eu vou utilizar essas analogia?"

6. Profa 6: Não, não. O nosso planejamento no papel, é uma cópia daquilo que tá lá no PEIS; não fica muito fora daquilo ali. E na parte, assim, de metodologia, de estratégia, eu boto.... essa parte de analogia, eu nunca botei no planejamento no papel. Tem umas que já são antigas, eu vi que funcionou, e eu continuei, né, usando. Mas assim, as vezes, né, sai ao acaso.

7. Entrevistadora: E desde quando tu usas esse recurso?

8. Profa 6: Eu sei, assim, por mim. Eu sou muito de, na hora de memorizar as coisas, eu sempre faço analogias. Eu comparo, inclusive com as crianças em casa, eu sempre procurei 
passar dessa forma. Talvez já venha, já de bastante tempo. Eu nem sei de quando. Se foi desde o começo. Desde o tempo de faculdade eu me lembro que eu fazia muito disso. Pra memorizar, eu comparava, com certas coisas.

A grande maioria das analogias utilizadas pelas professoras não foram planificadas com anterioridade à aula, geralmente, elas apareciam de uma forma espontânea na hora de explicação, geralmente, quando a professora percebia que os alunos não conseguiam compreender a explicação inicial, que o aluno ficava com dúvida:

\section{SEQÜÊNCIA 05}

1. Profa. 3: No planejamento eu nunca fiz planejamento de analogia. É conforme a aula tá indo. Normalmente tu tá falando uma coisa, tu olha que eles ficam assim, meio né, eles não te questionam, mas eles ficam te olhando meio abobalhados, meio.... aí tu sabe que alguma coisa tá errada, então tu... eu puxo da minha cabeça e faço uma relação: "Oh, aqui né..." Normalmente nem todos, mas sempre um grupo olha e te: "Ah!" Tu nota que já abriu sabe.

\section{SEQÜÊNCIA 06}

1. Profa. 5: Ela é espontânea (referindo-se ao uso de analogias) Às vezes eu nem me programo para usar aquela analogia, mas eu expliquei uma vez e vi que não ficou bem, que eu não consegui chega até eles, não consegui passa o recado, aí eu vou explicar uma outra vez, pra não fica igual a explicação, por que a gente sempre tenta muda alguma coisa né, daí usando a analogia chama mais a atenção, tenta fixa.

Quando perguntávamos às professoras sobre suas idéias acerca do papel das analogias como recurso didático para procurar obter dados referentes a preocupações e expectativas do professor em situação de aula ao usar analogias, obtivemos um resultado positivo em relação a esse item, ou seja, as professoras achavam que as analogias contribuíam no sentido de trazer um elemento do cotidiano dos alunos, e isso facilitava a explicação do conteúdo científico:

\section{SEQÜÊNCIA 07}

1. Entrevistadora: Qual a tua idéia acerca do papel das analogias como recurso didático?

2. Profa 1: Pra mim é ótimo. Se não fossem as analogias... se não tivesse como comparar uma coisa com a outra, era muito mais difícil dos alunos entenderem, sabe, as analogias que tu usa, tu geralmente, compara com o cotidiano deles, coisas que eles usam no cotidiano, que eles conhecem. Aí, fica muito mais fácil. Tu não faz analogias com coisa que eles desconhecem...não. É coisa da vida diária deles, sabe? Isso é muito importante...sabe, é como se tivesse passando do livro pra vida deles entendeu? É como se eles tirassem do livro e passassem pra vida diária deles. Isso é importante, porque não pode ficar ali, a vida separada do livro, né. A intenção é essa. Tu passar a matéria pra vida deles, tentar explicar, juntar os dois mundos, aqui da escola e lá de fora, né. Não distanciar, é aproximar, então tu usa as analogias, tu aproxima, né. É bem mais fácil. É ótimo. 


\section{SEQÜÊNCIA 08}

1. Entrevistadora: $O$ que que tu pensas sobre o papel das analogias como recurso didático?

2. Profa 6: Eu acho que é ótimo. É válido. Basta ver que onde eu posso usar, eu to colocando no meio. Eu gosto muito, memorizo muito através disso. Tu tem um retorno.

No entanto, algumas professoras, ao mesmo tempo que achavam que as analogias contribuíam para facilitar a compreensão inicial de um certo conteúdo, ficavam com dúvidas em relação a como estas deveriam ser usadas, achavam que deveria ter-se certo "cuidado" ao usar analogias já que essas poderiam estar promovendo uma idéia errada:

\section{SEQÜÊNCIA 09}

1. Profa. 6: Eu acho que a analogia facilita. Eu acho que eu vou me repeti até né. Eu acho que facilita mas, as vezes, eu me questiono, né, se não vai dar uma idéia errada, né. Algumas.... por que a gente usa assim... é espontâneo, as vezes, a gente pode ser mais feliz e as vezes menos feliz na associação que a gente vai faze né. Por que, tipo assim, tem umas que não tem erro né, associa o tubo digestivo como tubo, não tem chance de erra nisso aí. Mas outras, a gente pode ser menos feliz na analogia e passa uma idéia errada pro aluno.

\section{SEQÜÊNCIA 10}

1. Profa. 2: Como eu te disse, eu acho que é um bom recurso (as analogias). Só que eu acho ainda que tem que se tomar bastante cuidado, né. Não usar analogia em todo o conteúdo, em qualquer hora, em qualquer momento, né, por que aí fica meio complicado, né. O aluno passa a enxerga isso como sendo a aula em si. Eu acho que a analogia tem que ser bem clara, bem explicada né. Salientando pró aluno que é uma comparação aquilo ali, né. Eu acho bom, mas eu acho que tem que ser bem estudada, bem avaliada, né, pra ver se ela serve realmente pra aquele fim, pra aquele conteúdo.

Percebemos que o maior medo das professoras é que os alunos possam reter mais o conceito análogo em detrimento do alvo e na hora de explicação propor o análogo. A este fato talvez se deva o receio em usar este tipo de recurso:

\section{SEQÜÊNCIA 11}

1. Entrevistadora: Desde quando que tu usas este tipo de recurso?

2. Profa. 5: Analogia?

3. Entrevistadora: É.

4. Profa. 5: Eu acho que eu sempre usei, por que, ah, é uma coisa que não e planejada, então assim... e também assistindo outros cursos que a gente vê outros professores usando, então, que facilita o entendimento. E aí, tu passa a ... até usar, até não te sentir mal por usar aquele, aquele instrumento.

5. Entrevistadora: Como assim não te sentir mal?

6. Profa. 5: Não. Não sentir errada.

7. Entrevistadora: Que tipo de curso que tu participaste sobre analogias? Não foi curso específico sobre analogias? 
8. Profa. 5: Não, não. Curso comum. Os professores do curso usavam várias analogias. E eu nunca esqueço uma que o Elgio colocou como exemplo, quando ele tava falando do centríolo. Ele usou que era 0 .... associou assim como o ... pra dar estrutura pra célula, ele associou a célula como uma barraca e o centríolo como se fosse o suporte, o pau da barraca. $E$, até ele fez um parêntese, né, que as vezes as analogias leva o aluno a ficar com a idéia só da analogia. Não consegue abstrair realmente o que a analogia significa. Então, às vezes, a analogia pode ser problemática.

9. Entrevistadora: E aí ele deu alguma sugestão pra resolver esse tipo de problema?

10. Profa. 5: Não. Ele colocou isso por que ele, assim oh, ficou surpreso quando ele pegou uma avaliação de uma aluna, e era uma aluna da medicina, quando a aluna escreveu na prova, exatamente o que ele tinha dito. A analogia que ele tinha citado. Eu me questiono bastante né. Mas é que no momento que tu tá explicando, às vezes, tu vê que, que tu tem que acha um jeito do aluno associa com alguma coisa, por que a biologia é tão cheia de nomes né. Pra eles é tanto nome diferente, numa aula só. Muitas vezes eles mesmo dizem: "Aí professora, tu fala numa linguagem que a gente entende". Ou então, que eu vou ensinar um conteúdo que alguém já ensinou e que eles não fixaram: "Ah professora, mas assim ficou mais fácil”. Então... eu não sei, eu também não sei se eu to certa usando analogias, né.

É procedente a dúvida das professoras em relação ao uso de analogias, já que, como foi discutido anteriormente, se não for dada a devida atenção no momento do uso deste tipo de recurso didático, corre-se o risco de levantar um número maior de concepções alternativas e não alcançar os objetivos propostos para uma atividade de ensino. No entanto, para que se torne um recurso efetivo é necessário tomar-se determinados cuidados na hora de se trabalhar com analogias, o que é discutido a seguir.

\section{CONSIDERAÇÕES FINAIS}

As observações das aulas das professoras e as entrevistas realizadas revelaram, que, ao usarem analogias as professoras o fazem de uma forma espontânea, lançando mão de recursos de docência. Entre estes recursos estão as analogias, que, sem dúvida alguma, auxiliam o processo de ensino. Sendo espontâneas, as analogias utilizadas pelas professoras sujeitos da pesquisa, eram provenientes, na maioria das vezes, de um "insight", da própria criatividade ou do improviso. Isto provoca uma aparência de espontaneismo. Mas, na verdade, poderíamos especular que estes recursos seriam alguns dos constituintes imprescindíveis do saber-fazer docente. Este saber-fazer é diretamente influenciado pela sensibilidade das professoras que ao perceberem a estranheza de seus alunos para com determinado conteúdo fazem intervenções educacionais, sem que estas sejam previstas a priori. Quer dizer, lançam mão de algum tipo de recurso para que os mesmos compreendam melhor. A utilização destes recursos permite, entre outras coisas, a emergência de analogias originais que surgem em suas salas de aula oportunizando uma aproximação maior do cotidiano real dos alunos.

Reconhecemos o papel fundamental do uso de analogias no trabalho docente e reafirmamos o seu uso como um dos recursos didáticos que norteará o trabalho do 
ENSAIO - Pesquisa em Educação em Ciências

professor. Porém, o professor deve possuir um conhecimento didático para mediar e reconhecer quais recursos adotados no ensino poderão contribuir para ajudá-lo. Nesse sentido, um conhecimento da teoria relacionada a esse tipo de recurso por parte dos professores que a utilizarão bem como conhecimento das discussões sobre as vantagens e desvantagens das estratégias de ensino com analogias devem ser consideradas pelos professores.

Tendo um conhecimento relacionado ao uso de recursos como analogias os professores terão condições de fazer seu planejamento usando as analogias de uma forma mais estruturada. Porém, essa forma mais organizada de pensar o uso de analogias não deve ser um simples transplante de uma estratégia já constituída para ser aplicada em sala de aula, mas sim uma construção resultante das pesquisas na área, do uso espontâneo pelos professores e do uso pelo próprio aluno.

Por fim, os resultados desta pesquisa mostram que se faz urgente, na formação inicial e continuada dos professores, a inserção e discussão da questão sobre o uso de analogias no ensino, sua função, suas utilidades, suas vantagens e desvantagens, enfim, como usar analogias de uma forma efetiva. 


\section{REFERÊNCIAS BIBLIOGRÁFICAS}

CURTIS, R. V.; REIGELUTH, C. M. (1984). 'The use of analogies in written text'. In: Instructional Science, 13, pp.99-117.

DAGHER, Z. (1994). 'Does the use of analogies contribute to conceptual change?' In: Science Education, 78 (6), pp.601-614.

. (1995). 'Analysis of analogies used by science teachers'. In: Journal of Research in Science Teaching, 32 (3), pp.259-270.

DUIT, R. (1991). 'On the role of analogies and metaphors in learning science'. In: Science Education, 75 (6), pp.649-672.

GLYNN, Shawn M.; LAW, Michael; GIBSON, Nicole; HAWKINS, Charles H. (1998). 'Teaching science with analogies: a resource for teachers and texbooks authors'. Disponível em: <http://curry.edschool.virginia.edu/go/clic/nrrc/scin ir7.html>

HARRISON, Allan G.; TREAGUST, David F. (1994). 'Science Analogies: avoid misconceptions with this sistematic approch'. In: The Science Teacher, 61, pp.40-43.

IDING, Marie K. (1997). 'How analogies foster learning from science texts.' In: Instructional Science, 25, pp.233-253.

OGBORN, Jon; MARTINS, Isabel. (1996). 'Metaphorical understandings and scientific ideas'. In: Int. J. Sci. Educ., 18 (6), pp.631-652.

TERRAZZAN, E. A.; AMORIM, M. A. L.; PIMENTEL, N. L.; FELTRIN, C.; DIAS, D. S.; FERRAZ, D. F.; SILVA, L. L.; POZZER, L. L.; GIRALDI, P. M. (2000). 'Analogias no ensino de ciências: resultados e perspectivas'. In: Anais do III Seminário de Pesquisa em Educação da Região Sul, Porto Alegre/BRA.

THIELE, R.; TREAGUST, D. (1994). 'An interpretative examination of high school chemistry techers' analogical explanations'. In: Journal of Research in Science Teaching, 31 (3), 227242.

THIELE, R.; TREAGUST, D. (1995). 'Analogies in chemistry textbooks'. In: International Journal of Science Education, 17 (6), pp.783-795.

TIERNEY, D. S. (1988). 'How teachers explain things: metaphoric representantion of social studiesconcepts.' In: Annual Meeting of the American Educational Research Association.

TREAGUST, D. F.; DUIT, R.; JOSLIN, P.; LINDAUER, I. (1992). 'Science teachers use of analogies: observations from classroom practice'. In: Int. J. Sci. Educ., 14 (4), pp.413-422. 
ENSAIO - Pesquisa em Educação em Ciências

VENVILLE, G. J.; TREAGUST, D. F. (1996). 'The role of analogies in promoting conceptual change in biology'. In: Instructional Science, 24, pp..295-320.

WILBERS, J.; DUIT, R. (2001). 'On the micro-structure of analogical reasoning: the case of understanding chaotic systems'. In: BEHRENDT, H. et al. Research in Science EducationPast, Present and Future. Netherlands: Kluwer Academic Publisher. pp. 205-210. 